\title{
Physical Economics and Optimum Population Density
}

\section{Paul T E Cusack}

1641 Sandy Point Rd, Saint John, NB, Canada E2K 5E8, Canada

*Corresponding author: Cusack PTE, Independent Researcher, BSc E, DULE, 1641 Sandy Point Rd, Saint John, NB, Canada E2K 5E8, Canada, Tel: (506) 214-3313; E-mail: St-michael@hotmail.com

Received date: January 17, 2017, Accepted date: March 23, 2017, Published date: March 30, 2017

Copyright: (c) 2017 Cusack PTE. This is an open-access article distributed under the terms of the Creative Commons Attribution License, which permits unrestricted use, distribution, and reproduction in any medium, provided the original author and source are credited.

\begin{abstract}
s
Here we examine the economic problem of what is the optimum population density (300 persons/km²)? We use mathematics from Economics, and concepts such as the marginal propensity to consume to determine it. We calculate the optimum taxation rates (48\%). We invent a concept author call the Minderland, comparable to the Cusack hinterland factor (6.47). Data from the US, Europe and the Great Toronto Region are used along with Linear Regression techniques.
\end{abstract}

Keywords: Cusack hinterland factor; Gravitational constant; Minderland; Optimum taxation; Multiplier; MPC

\section{Introduction}

In examining the Regional Disparities of the Saint John New Brunswick, Canada region, I theorized that there might be a population density that is optimum for economic performance of a City and Region and Country New Brunswick has a population density of just 10 people per square $\mathrm{km}^{2}$. That is far too low to compete with the likes of Toronto, Vancouver, and Boston. It's interesting that the population density of the 1970s Toronto Centered Region (now the GTA, Hamilton, Kitchener Waterloo, Barrie, and Peterborough) has a 2006 population of 6,993,689 Million people. With an area of 22,270 $\mathrm{km} 2$, (Saint John region is $24,000 \mathrm{~km}^{2}$ ) there is a population density of 314 persons $/ \mathrm{km} 2$ - not far off the 300 persons $/ \mathrm{km}^{2}$ optimum considering that the Toronto Region is the best performing Economic Region in Canada. Does the relationship hold elsewhere?

\section{The United States}

Author looked at the US States. The basic data of population per state and GSP were available on the Wikipedia internet site. In the USA, note the following maps: One of gross domestic product (GDP) per State and one of the Populations per State. There is a direct correlation between Population of a given State and the GDP per state. A statistical regression analysis was done and it was determined that the range of populations were from 544,270 in Wyoming to 36,961,664 in California. The GSP ranged from $\$ 25,442$ Million in Vermont to $\$ 1,846,757$ Million in California the R squared correlation coefficient was 0.97 for these two variables. When the GSP PER CAPITA was compared, there was found to be no correlation ( $\mathrm{R}$ squared $=0.36$ ). This suggests that the higher a state's population, the higher will be the GSP/GPP with confidence. The $\mathrm{R}^{2}$ for the US states alone is $0.44-$ slightly higher. This suggests that if the government wants to increase the absolute GNP of a Province, Region or a State or even country, it must increase the population to the optimum density of about 300 persons $/ \mathrm{km}^{2}$. This will not necessarily increase the GSP per capita. The function: $\mathrm{Y}=45.8994825 \times+33,224$ has a derivative of 45.9 or say 46 . This is the incremental amount added to a Regional Economic Domestic Product, viz 1 person per $\mathrm{km}^{2}$ adds $\$ 46$ to the GSP or GPP.
This means that for each person in density per square kilometer in density a region has, then income goes up by $\$ 46$ per capita per year. It appears to be a linear function. Therefore, higher densities mean higher gross products. If we consider Critical Mass from nuclear Fission in the physical sciences: A numerical measure of a critical mass is dependent on the neutron multiplication factor, $\mathrm{k}$ :

\section{$\mathrm{K}=\mathrm{f} / \mathrm{l}$}

Where $\mathrm{f}$ is the average number of neutrons released per fission event and 1 is the average number of neutrons lost, either by leaving the system or being captured in a non-fission event. When $\mathrm{k}=1$, the mass is critical.

So, applying the formula:

$\mathrm{f}=$ Average \# of neutrons released per neutron

$\mathrm{l}=$ Average number of neutron lost per fission

$\mathrm{k}=$ Critical mass.

MPC=Marginal propensity to consume

$\mathrm{K}=\mathrm{HLF} /$ Multiplier/1/Multiplier

HLF/Multiplier $\times$ Multiplier $=$ HLF

$\mathrm{HLF} /$ multiplier $\times 1 /(1 / \mathrm{MPC})=\mathrm{HLF} /$ Multiplier $\times(1-\mathrm{MPC})$

$\mathrm{HLF} /$ Multiplier $\times(1-\mathrm{MPC})=\mathrm{k}=1$ or

$\mathrm{HLF} / 7 \times[1-(1 / 7)]=\mathrm{HLF} / 6=\mathrm{k}$

$\mathrm{k}=\mathrm{HLF} / 6$

When the HLF=6, then $\mathrm{k}=1$ which is the critical mass definition form nuclear physics.

Further from algebra, it can be shown that:

$\mathrm{K}$ critical=MPC/(1-MPC), where $\mathrm{MPC}=$ Marginal Propensity to consume.

This is the Cusack Population Critical Mass equation.

So, with a multiplier factor of about $7, \mathrm{~K}=(6 / 7) /(1 / 7)=6=$ This is the Cusack Hinterland Factor

It is actually $314 / 45.8994825$ \$US (1.066 \$US/\$Can in 2008)=6.417 
Page 2 of 6

(Nb:cf w/the Gravitational constant $\mathrm{G}=6.6732$ Newtons $\mathrm{m}^{2} / \mathrm{kg}^{2}$.

Force is proportional to Mass $\times$ acceleration

$\mathrm{F}=\mathrm{Ma}$ or $\mathrm{F}$ (gravitational $)=\mathrm{M}_{\mathrm{g}}=\mathrm{M} \times 9.81 \mathrm{~m} / \mathrm{s}^{2}$

$\mathrm{F}$ is proportional to $\mathrm{kg} \times \mathrm{m} / \mathrm{s}^{2}$

$\mathrm{F}$ is proportional to $\mathrm{kg} \times \mathrm{m} / \mathrm{s}^{2}$

$\mathrm{F}^{\wedge}-1$ is proportional to $\mathrm{kg} \times\left(9.81 \mathrm{~m} / \mathrm{s}^{2}\right)$

$\mathrm{F}^{\wedge}-1$ is proportional to $\mathrm{kg} \times(10) \mathrm{kg} / \mathrm{m}^{2}$

and ,

Cusack HLF $=\left[6.67\right.$ persons $\left./ \mathrm{km}^{2}\right]=[6.67 \wedge-1] /[1-6.67]=0.85 / 1 /$ (1-0.85)

$6.67=$ Gravitational constant

and,

It can be shown by algebra that: Gravitational constant $=\mathrm{G}=6.6732$ is proportional to [(1-MPC)/MPC]+1

Therefore the CHLF proportional to Gravitational Force ${ }^{\wedge}-1[=]$ $\$ / \mathrm{km}^{2}$

It can be shown by algebra that if there is a certain decrease in population percentage, then the MPC changes to: MPC (new)=1 $[1 /(\mathrm{G}-$ Delta $\%)]$

So for a 33\% decrease in population, such as had in Saint John from 1971 to 2010 :

The MPC would have had to increase to 0.98 from 0.85 . In other words, practically all the money earned by the remnant would have had to be spent except $2 \%$.

The Marginal Propensity to Consume (MPC): Taxes in Canada are average $42.6 \%$, and, the series of a MPC: $\operatorname{Sum}\left\{(0.15)^{\wedge} 0+(0.15)\right.$ $\wedge 1+(0.15)^{\wedge} \quad 2+\quad(0.15)^{\wedge} 3+(0.15) \quad \wedge 4+(()$. $\left.15) 5+(0.15)^{\wedge} 6+(0.15)^{\wedge} 7\right]=0.4879$

Income-Taxes-Savings $=(1-\mathrm{MPC})=1.00-42.8 \%-0.4879-(1-\mathrm{MPC})$ $2 \mathrm{MPC}-\mathrm{MPC}^{\wedge} 2=0.4879-\mathrm{MPC}$

Taking the $\ln$ of both sides: $\ln (2 \mathrm{MPC})-2(\ln (\mathrm{MPC})=0.858530$

Raising to the base $\mathrm{e}=2.18$

MPC $=0.845678$

$[\$ 1.00-42.6 \%]-(1-\mathrm{MPC})]=0.4879$

From algebra: $1=\mathrm{MPC}-\mathrm{MPC}^{\wedge} 2$

Taking the ln of both sides,

Ln $1=-\ln \mathrm{MPC}$

$0=-\ln$ MPC

raising both sides to base e,

$1=\mathrm{MPC}-\mathrm{T} / \mathrm{Y}$

[T/Y] MPC $=0.367879$

MPC $=0.367879 \times 1 / 42.8 \%=0.859530$

If total taxes were lowered from $42.8 \%$ to say $40 \%$, then: $\mathrm{MPC}=0.367879 \times 1 / 40 .=0.919698$. Therefore "K critical" would change.
K critical=MPC $/(1-M P C),=.919698 / 1-0.919698=11.45$

$1=[(1-\mathrm{MPC})(\mathrm{MPC})] /[\mathrm{Tax} / \mathrm{Y}]$

Cusack HLF $=1 /\{(1-.917879)(.917879) /[40 \%]\}=5.30$ persons $/ \mathrm{km}^{2} \mathrm{cf}$ 6.6732

So, a lower critical number of people would be need to keep the monetary reactions going. Lowering taxes in a depressed area would result in a lower Cusack Hinterland factor.

For each percent drop in total taxes: $1=[(1-\mathrm{MPC})(\mathrm{MPC})] /[\mathrm{Tax} / \mathrm{Y}]$

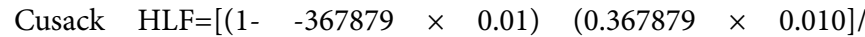
$[0.01]=(0.996321) \quad(0.003679) / .01=0.366526$ drop per percentage change in total taxes

This means that the $\mathrm{K}$ critical is dropped by $5.45 \%$ for a $1 \%$ change in the total tax rate.

To maximize: $\mathrm{K}$ critical $=\mathrm{y}=[(1-\mathrm{MPC})(\mathrm{MPC})] / \mathrm{T}$

$\mathrm{dy} / \mathrm{dMPC}=(1-2 \mathrm{MPC}) / \mathrm{T}$

set equal to 0

$0=[1-2 \mathrm{MPC}] / \mathrm{T}$

$\mathrm{MPC} / \mathrm{T}=1 / 2=0.5$

$\mathrm{MPC}=0.5 \mathrm{~T}$

$\mathrm{T}=2 \mathrm{MPC}$

$\mathrm{CHLF}=\mathrm{k} \quad$ critical $=[(1-\mathrm{MPC}) \quad(\mathrm{MPC}) \quad] / 2 \mathrm{MPC}==[(1-0.5)(0.5)] /$ 2MPC $=0.25 / 2 \mathrm{MPC}$

$=0.5(1 / \mathrm{MPC})$

$=0.5(1 / 0.5)$

$\mathrm{k}$ critical $=1$

K Critical v. Total Tax

K Critical Values above 0

Tax/Y MPC K critical

Note: This is $\mathrm{K}$ the critical Taxrate is asymptotic at about 48 (the derivative of the regression plot is $45.899 \$ /$ person $/ \mathrm{km}^{2}$ ) and minimized at about $55 \%$. This means that the optimum Taxrate is $55 \%$ since $\mathrm{K}$ critical must be $>0$.

\section{Tax/Y MPC K critical}

Above this figure, energy is wasted or divided among more people, thus a lower per capita income. Below this figure, the critical mass is not reached. That's why the universe is stable at the Gravitational constant and Planks constant. And that is why the cities populations perform at a maximum optimally at a $\mathrm{HLF}=6.71 \$ / \mathrm{km}^{2}$.

Here's one for the Physicists: The Gravitational Field is the same as the field surrounding a city centre. In large mega metropolis, the satellite cities are areas of high mass density (black holes?) and when we substitute dollars \$ for Mass $\mathrm{kg}$, we have a black hole at the city centre.

This is an interesting finding: $F=G[M 1 M 2] / D$

$\mathrm{Ma}=\mathrm{G}$ M1 M2/D

$\mathrm{a}=6.6732\left(10^{\wedge}-11\right)(\$ 48) /$ person $/ \mathrm{km}^{2}=320.31 \$ /$ person $/ \mathrm{km}^{2}$

But 
Page 3 of 6

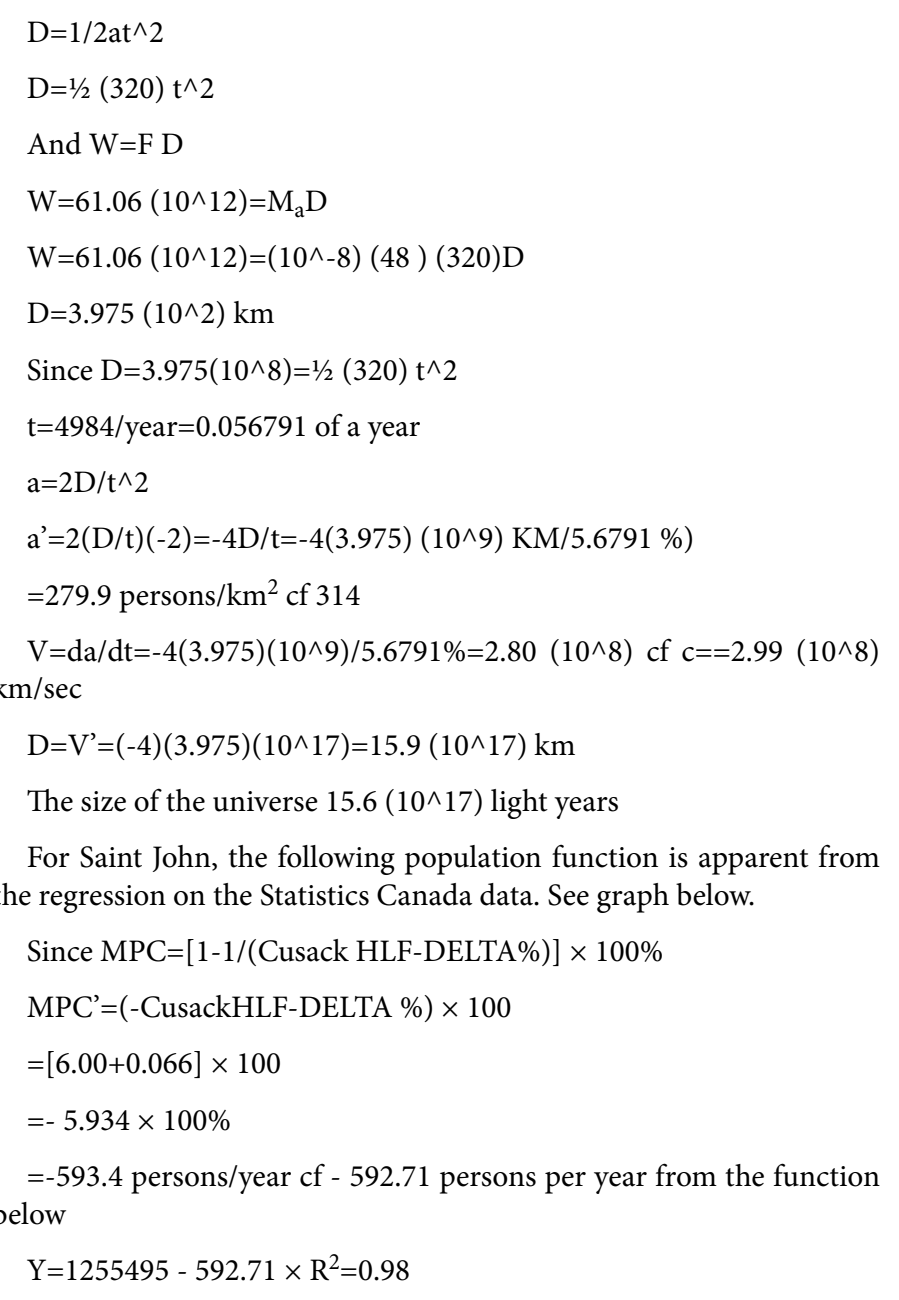

Y Predicted $\times$ Actually anywhere in Physics we have Mass $(\mathrm{kg})$, we can substitute money (\$).

For example,

$\mathrm{E}=\mathrm{Mc}^{\wedge} 2$

$\left.61.06\left(10^{\wedge} 6\right) \$ \mathrm{~km}^{2} / \mathrm{s}^{2}=\mathrm{M} \times\left(2.997925 \times 10^{\wedge} 5\right) \mathrm{km} / \mathrm{s}\right)^{\wedge 2}$

$\mathrm{M}=61.06\left(10^{\wedge} 6\right) / 8.98\left(10^{\wedge} 10\right)$

$=\$ 6.79$

Momentum $\mathrm{P}=\mathrm{Mv}$

Capital Tends to accumulate: $F($ gradational force $)=G \times[M 1 \times$ $\mathrm{M} 2] / \mathrm{D}$ (mass is money \$ not people)

Work $\mathrm{W}=\mathrm{F} \times \mathrm{D}=(\mathrm{M} \times \mathrm{a}) \times \mathrm{D}$

Kinetic Energy $\mathrm{KE}=1 / 2 \mathrm{Mv}^{2}$

Potential Energy PE=Mgh

Conservation of energy PE1+KE1=KE2+PE2

$\mathrm{D}=1 / 2$ a $\mathrm{t}^{\wedge} 2$

Total Energy=Potential energy+Kinetic Energy

P.E $=\mathrm{Mgh}$

$\mathrm{K} . \mathrm{E}=1 / 2 \mathrm{M} \mathrm{v}^{\wedge} 2$
Savings,

P.E. $=\mathrm{M} \mathrm{g} \mathrm{h}$

$(1-\mathrm{MPC})(61.06) 10^{\wedge} 12=6.6732 \times 9.81 \times \mathrm{h}$

[(1-MPC) $(61.06) 10^{\wedge} 12$ ]/6.6732 10^-11 $\times 9.81\left(10^{\wedge}-3\right)=\mathrm{h}$

[(1-MPC) 61.06 ] $10^{\wedge} 23 / 6.6732 \times 9.81=\mathrm{h}$

[(1-MPC) $\left.\left.0.9327251\left(10^{\wedge} 23\right)\right] / G+1 /\left\{9.8110^{\wedge}-3\right)\right\}=(1-\mathrm{MPC}) 10^{\wedge} 23$

$\mathrm{G}=6.6732\left(10^{\wedge}-11\right)$

From the distance equation in physic

$\mathrm{D}=1 / 2$ at $\wedge 2$

$\mathrm{a}=2 \mathrm{D} / \mathrm{t}^{\wedge} 2$

and

$\mathrm{F}=\mathrm{G}$ M1 M2/D

$\mathrm{F} \times \mathrm{D}=\mathrm{G}$ M1 M2

$\mathrm{M}$ a $\mathrm{D}=\mathrm{G}$ M1 M2

$2 \mathrm{D} / \mathrm{t}^{\wedge} 2=\mathrm{GM}$

$\mathrm{G}=2 \mathrm{D}^{\wedge} 2 /[\mathrm{t} \wedge 2 \mathrm{M}]$

Derivative with time:

$\mathrm{dG} 2 / 2 \mathrm{t}^{\wedge} 2=2 \mathrm{D}^{\wedge} 2 / \mathrm{M}[=] \mathrm{km}^{\wedge} 2 / \$$ where Mass $\mathrm{kg}$ is substituted for dollars.

$\mathrm{G}=2 \mathrm{M} / \mathrm{D}^{\wedge} 2$

$=2 \mathrm{M} / 1^{\wedge} 2 \mathrm{~km}^{\wedge} 2$

$\mathrm{M}^{\prime}=0.5$ which is $\$ 50.00 / \mathrm{km}^{2} \mathrm{cf} \$ 45.899 / \mathrm{km}^{2}$

If we take the gravitational equation and substitute dollars $\$$ for Mass kg:

\section{$\mathrm{F}=\mathrm{GM} 1 \mathrm{M} 2 / \mathrm{D}$}

But $\mathrm{F}=\mathrm{Ma}=\mathrm{Mg}$

and $\mathrm{D}=1 / 2 \mathrm{at} \wedge 2$

Therefore $a^{\wedge} 2 t \wedge 2 / 2 G$ is proportional to $M$

But, from elementary Newtonian Physics $\mathrm{da} / \mathrm{dt}=\mathrm{V} \quad \mathrm{dV} / \mathrm{dt}=\mathrm{d}$ therefore $\mathrm{da} " / \mathrm{dt}=\mathrm{D}$

$\mathrm{a}^{\wedge} 2 / 2 \mathrm{G}$ is proportional to: $\mathrm{M}$

$2 \mathrm{a} / 2 \mathrm{G}=\mathrm{M}$

$\mathrm{a} / \mathrm{G}=9.81 / 6.6732=\mathrm{M}$

$\mathrm{M}=1.470059 /$ Newton $\mathrm{m}^{\wedge} 2$

$\mathrm{M}^{\wedge}-1=0.68$

$(0.68)^{\wedge} 2=\$ 46.24 / \mathrm{km}^{\wedge} 2 \mathrm{cf} \$ 45.89 / \mathrm{km}^{2}$

If we consider the gravitational equation again where $\mathrm{M} 1=\mathrm{M} 2$ (neighbouring houses same price):

$\mathrm{F}=\mathrm{G} M 1 \mathrm{M} 2 / \mathrm{D}$

$\mathrm{dF} / \mathrm{dD}=-\mathrm{G} \mathrm{M} 1^{\wedge} 2 / \mathrm{D}^{\wedge} 2$

$\mathrm{dF} " / \mathrm{dD}^{\wedge} 2=-\mathrm{G} M 1^{\wedge} 2 / 2 \mathrm{D}$

$=-1 / 2 \mathrm{G} \mathrm{M}^{\wedge} 2 / \mathrm{D}$ 
Page 4 of 6

per $\$ 1000$ home value per $1 \mathrm{~m}$ distance:

$\mathrm{dF}^{\prime \prime} / \mathrm{dD}^{\wedge} 2=-1 / 2\left(6.6732\left(10^{\wedge}-11\right)\right) / 1$

$=-\$ 3.33666\left(10^{\wedge}-5\right) /$ thousand $/$ metre

$\mathrm{G}$ is proportional to 6.6732

$\mathrm{M}=333.66$ persons $/ \mathrm{KM}^{\wedge}{ }^{2} \mathrm{cf} 314$ person $/ \mathrm{km}^{2}$

Kinetic Energy:

$\mathrm{K} . \mathrm{E}=1 / 2 \mathrm{M}$ v ${ }^{\wedge}$

$61.06\left(10^{\wedge} 12\right)=\left[(1 / 2 \times 6.6732(10-11)(10-3)]^{\wedge} 0.5 \times \mathrm{v}\right.$

$\mathrm{v}=10.57\left(10^{\wedge} 18\right)$

Work:

$\mathrm{W}=\mathrm{F} \times \mathrm{d}$

$=\mathrm{M} \times \mathrm{a} \times \mathrm{d}$

$=6.67329\left(10^{\wedge}-11\right) \times 9,81\left(10^{\wedge}-3\right)\left(10.57\left(10^{\wedge} 12\right)\right)$

$=6.920(10-3)$

$\$ 61.06\left(10^{\wedge} 12\right)=6926.1\left(10^{\wedge}-3\right) \mathrm{KJ} / \mathrm{s} / 6.3\left(10^{\wedge} 9\right)$ persons

$\$ 1399.00 /$ person/day/2000 h work/year

$=\$ 0.10 / \mathrm{h} \times 8$ hours $=\$ 0.80 \$ /$ day spent

With a $\mathrm{MPC}=0.85$

The average wage per day is $\$ 0.94 /$ person/day

Furthermore, $(1 / 7)=0.1428 \times 308$ person $/ \mathrm{km}^{2}=\$ 43.98$ or say $\$ 44 /$ person

This compares well with the derivative of the above Income $\mathrm{Y}$ function.

$\$ 45.9 \times 6.7=$ persons or say 306.53 persons/KM@ for a critical mass, say 300 .

This has further implications. For example, if we examine an outward migration, the $\mathrm{k}$ critical fact decreases and people who stayed behind must SPEND MORE to maintain a critical factor of 6 .

$$
\begin{aligned}
& \mathrm{k}=\mathrm{f} / \mathrm{l} \\
& \mathrm{k}=[(6-1) /(7-1)] / 1 ; /[(7-1)]=5 /(1 / 6) \\
& 5 / 6 \times 6 / 1 / 1 / 6 \\
& 5 \times 6=30
\end{aligned}
$$

If $\mathrm{k}=30$ instead of 6 as the critical factor, then one must spend $\$ 46.00 \times 30=1380$ person $/ \mathrm{km}^{2}$. instead of 3000 person $/ \mathrm{km}^{2}$ so the population must increase dramatically and spending must increase as a portion of income. Therefore, once outward migration starts, its impossible to stop unless those with deep pockets spend. Federal Government policy toward the Maritime Provinces has left the Maritime economy in shambles due to its outward migration policies. However, when a similar analysis was undertaken for 57 countries, their GDP per Capita showed absolutely no correlation to Population Density. The Regression analysis showed a scatter plot (Below) that has an $\mathrm{R}$ squared of 0.001 i.e., no correlation between the two variables. For the City of Saint John, New Brunswick, for example, with an area of $318 \mathrm{~km}^{2}$ and a population of about 66,000 , for every 318 people population increase, the GPP goes up by $\$ 856,000$ to the local economy. This linear relationship works in reverse also. If further studies were undertaken, it would seem that perhaps regional economies such as Toronto or Chicago for example may show a correlation for these two variables. Data would have to be collected for regional economies if GDP is available for a region as opposed to a state or country. There was found a weak correlation between City Pop Density and Per Captia Income (0.1), but a weaker correlation with City Population (0.07) What does this all mean? Since there is a high correlation of State population and Per Capita Income, drawing people to one's state will increase the Per Capita Income. Drawing people to one's country will not. Neither will drawing people to one's City. The reason must lie in the fact that the Cities have hinterlands. Hinterlands, or the State as a general proxy, are what is important to a per Capita income level.

\section{European data}

As another check on the regression line, we use the European Union Data.

Population $=501,259,850$

Pop Density $=115 \mathrm{~km}^{2}$

$\mathrm{Y}=46(115)+33224=\$ 38,514$ per capita cf $\$ 33,052$ (Source IMF Estimate)

Population $=501,259,850$

Pop Density $=115 \mathrm{~km}^{2}$

$\mathrm{Y}=46(115)+33224=\$ 38,514$ per capita cf $\$ 33,052$ (Source IMF Estimate) $\$ 38,524 \times 501,259,850=\$ 19.3$ Trillion cf. $\$ 16.447$ GDP ( “)

What would be the reason for higher density jurisdictions to have a higher income. An economist would say that people in those areas are creating more wealth and thus earn more. From my time in Ontario, one of the wealthiest jurisdictions in the world, I noticed empirically that people are willing to take more and greater risk. I suspect psychologists would find that higher densities lead to greater risk taking -the "Rat Race". Perhaps a Psychologist will undertake a study to see if this is true $[1,2]$.

\section{The Cusack Hinterland factor}

If we look at the Hinterland Area and Population, we find there is a linear relationship between percentage of HL Area/Total Area and the Population of the HL. This is described by the equation:

Population: $\mathrm{HL}=946087+410788$ (Area HL/Total Area of the Jurisdiction)

For Quebec, for example, which has a well-defined hinterland, the population of

7,866,108. Therefore:

$7,866,108=946,087+410788$ (Percentage of Area Total)

Area Total $=17.2 \%$ This compares with $17.7 \%$ in fact

Population HL=946,087+410788 (17.7)

Population of $\mathrm{HL}=8,217,034$ This compares favorably with 7,886,108

With algebra, it can be shown that:

Area HL $\left(\mathrm{km}^{2}\right)=$ Pop HL $\times 6.06$

Rearranged: 
Pop HL/Area HL=Density HL=6.06 $($ per km²)

Why is there a factor of 6.06 . Because the Earth's population is approximately 6.6 billion people. There are 1.48 billion $\mathrm{km} 2$ less Antarctica, Artic, and the Sahara Desert (1.05

$\left.\mathrm{km}^{2}\right) 1.48 \mathrm{~km}^{2} \times 6.06=8.9$ billion people which will be reached in 2030.

The maximum population the world can sustain at a multiplier effect of 7 and a savings rate at $1 / 7$ is 6 persons per km@. since the population of the earth is currently at that figure, not further population increase will permit an increase in wealth, unless patent value were to increase. This is treated below. This works because all wealth created comes from the land. Even services ultimately come from the land because the person providing the service had to consume food and location or a computer terminal to provide the service. All wealth is either a service or commodity (material and labour) or a transfer of wealth (such as legal fees for example). But since all wealth comes from the land then all the wealth on earth (World GDP) divided by the Earth land surface $=6.6$ billion people $/ 1.0$ billion $\mathrm{km}^{2}=6$. The closer a country, such as Canada, comes to the 6 persons $/ \mathrm{km}^{2}$, then the more it is based on Natural Resources, as Canada is. The larger the Hinterland is, either the country has stolen hinterland from another country or it is a more serviced based economy. If the sea is used for economic gain besides seafood, such as oil exploration, then the effectively the amount of land under 'cultivation" is increasing. This formula implies many interesting relationships of wealth to the land. But average worldwide wealth depend on about 1.5 acres per person. Even your computer comes from the earth (plastic=oil, copper, glass, etc.) The arrangement of these natural resources is a mental constructs and do not take form until the earth's resources are put into play. We will come to the end of growth of wealth when no more ingenious mental constructs can alter the use of the Earth's natural resources. Then we would have to look off the planet for additional wealth. This land exploration is what drives economies. That is why Western Europe -the explorers-became so wealthy. They increase the land under their control. If a city/region/ country exceeds the 6 persons $/ \mathrm{km}^{2}$, then that country will have poverty e.g., India, If a city/region/country is under the 6 person $/ \mathrm{km}^{2}$, then that country will grow e.g., Australia. Vancouver is short one million people so there will be a net influx of people into the Region. As a check, Saint John, New Brunswick has a hinterland of $24,000 \mathrm{~km}^{2}$ approximately. Therefore, the population should be around 144,000. It is actually 145,000 . so it works.

\section{MINDerland}

If we consider that the area of land on the planet is limited, to increase consumption beyond present capacity to match population growth, we therefore must get more out of our patents if we are to increase output. This is why the future for cities is in their creative ideas or for example university output. The future hinterland I the city is the

mind which I call MINDerland.

If we consider the formula:

$\mathrm{Y}=\mathrm{C}+\mathrm{I}+\mathrm{S}+\mathrm{G}+(\mathrm{IM}-\mathrm{E} \times)$

Where $\mathrm{Y}=\mathrm{GDP}$

$\mathrm{C}=$ Consumption

I=Investment
$\mathrm{S}=$ Savings

$\mathrm{G}=$ Government Spending

$\mathrm{T}=$ Consumption Tax

$\mathrm{Ex}=$ Exports

$\mathrm{IM}=$ Imports

HFL=Hinterland Factor

$\mathrm{P}=$ Value Patents

$\mathrm{M}=$ Material Employed

L=Labour Employed

Assuming Imports - Exports=0, it can be shown that:

$\mathrm{Y} / \mathrm{km}^{2}=\mathrm{HLF}[1+\mathrm{P} / \mathrm{L}+\mathrm{L}\}$

Or:

$\mathrm{GDP} / \mathrm{km}^{2}=6\{1+$ Patents/Population+Population)

Therefore:

$\left\{\mathrm{GDP} / \mathrm{km}^{2}\right\} /\{1+$ Patents/Population+Population $\}=6$

$\mathrm{GDP} /\{1+$ Patents $/$ Population+Population $\}=6 / \mathrm{km}^{2}$

The value of Ideas/Patents:

Patents $=6$ Population/GDP - Population -1

Patents $=6 \times 6.36 \times 10^{\wedge} 9 / 54.937 \times 10^{\wedge} 12-6.36 \times 109-1$

Patents $=0.65 / 10^{\wedge} 3-6 \times 10^{\wedge} 9-1$

Patents (Ideas) $=$ Population $=\$ 6$ billion per annum

Patents are estimated worldwide at 1 trillion dollars. At a historical Stock market return

at $8.4 \%$ per annum, $\mathrm{n}=99$, Patents and ideas are worth $\$ 604$ billion dollars

In Europe, there are about US $\$ 12.6$ billion of Patents. This is about $1 / 800$ of the EU

GDP. $\$ 20$ Billion/ $\$ 16.447$ Trillion EU GDP=0.15\%

\section{For the European Union}

$\mathrm{Y}=\mathrm{M}+\mathrm{L}+\mathrm{P}$

$16.447 \times 10^{\wedge} 12=\mathrm{M}+(\$ 29729 \times 510,259,000$ people $)+1.5 \times 109$

$\mathrm{M}=(16.447-14.9-1.5) \times 10^{\wedge} 9$

$\mathrm{M}=1544.4 \times 10^{\wedge} 9=\$ 1.5$ Trillion/year

As a cash flow at $3 \%$ :

Material $=\$ 150$. Trillion $=$ value of Real Estate

$\$ 150$ Trillion $/ 432 \times 10^{\wedge} 6 \mathrm{~km}^{2}=\$ 347222 / \mathrm{km}^{2}=\$ 8756 /$ acre looked at another way:

$\$ 1544000 \times 10^{\wedge} 6 / 4324 \times 10^{\wedge} 6 \mathrm{~km}^{2}=\$ 357 / \mathrm{km}^{2} / \mathrm{YR}$

Since:

$\$ 6 \times 10^{\wedge} 9$ Patents $/ \$ 6 \times 109$ people $=\$ 1.00$ patents $/$ person $/ \mathrm{yr}$

$\$ 1.00$ patents $/$ person $/ \mathrm{yr} / \$ 357 / \mathrm{km}^{2} / \mathrm{YR}=\$ 357$ person $/ \mathrm{km}^{2}$

The Capitalization Rate: 
$=\$ 45.899 /$ person $/ \mathrm{km}^{2} \times 1.3\left(10^{\wedge} 9\right) \mathrm{km}^{2}$

$=\$ 59.66\left(10^{\wedge} 9\right)$

$\$ 59.66\left(10^{\wedge} 9\right) / \$ 61.06\left(10^{\wedge} 12\right) \times 100 \%=9.7721 \%$

So, the EU also shows the optimum density of about 300 persons per $\mathrm{km}^{2}$

United States-Canada Wage Differential:

Investments:

$\mathrm{Y}=\mathrm{C}+\mathrm{I}+\mathrm{G}+\mathrm{S}+(\mathrm{IM}-\mathrm{E} \times)$

$61.06\left(10^{\wedge} 12\right)=\mathrm{M}+\mathrm{L}+$ Patents $+\mathrm{I}+0$

$\mathrm{M}=\mathrm{L}$

and, $2\left(30.53\left(10^{\wedge} 12\right)\right) / 200,000,000 \mathrm{~km}^{2}$ in the $\mathrm{G} 8=\$ 305,300 . / \mathrm{km}^{2}$

$305,300 \times \$ 45.899 / \mathrm{km}=\$ 14,012,964$

$(14,012,964)+\mathrm{I}+0.39 .6 \%\left(30.53\left(10^{\wedge} 12\right)=61.06\left(10^{\wedge} 12\right)\right.$

$\mathrm{I}=\$ 12.08989\left(10^{\wedge} 12\right)$

$\mathrm{Y}=\mathrm{M}+\mathrm{L}+$ Pat + Profit

Divide by Population POP

$(\mathrm{L}+$ Pat+Profit $) / \mathrm{POP}=(\mathrm{Y}-\mathrm{M}) / \mathrm{POP}$

$\mathrm{L} / \mathrm{POP}+(\mathrm{Pat}+\mathrm{Profit}) / \mathrm{POP}=\mathrm{Y} / \mathrm{POP}-\mathrm{M} / \mathrm{POP}$

Work force+( Pat+Profit )/POP=Per Capita Income - M/POP

Work Force $+($ Pat + Profit $)=\mathrm{Y}-\mathrm{M}$

From Algebra it can be shown that:

$\mathrm{L}=\mathrm{M} /((1+$ Profit $) \mathrm{Y}-$ Pat $)$

$\mathrm{L}$ is proportional to $\mathrm{M} /((1+$ Profit $) \mathrm{Y}-$ Pat $)$

If profits are assumed equal in Canada and the US at $10 \%$ :

And that the population of the US $=310,622,000$ and GDP $=\$ 14.256$ $\left(10^{\wedge} 12\right)$ the population of Canada $=34,301,000$ and the $\mathrm{GDP}=1.33$ $\left(10^{\wedge} 12\right)$

$\mathrm{L}=1 /(\mathrm{A}-\mathrm{B})$

$\mathrm{B}$ is proportional to $\mathrm{A}-1 / \mathrm{L}$

Therefore

Pat are proportional to $\mathrm{Y}$

$\mathrm{L}$ us/L can $=310,622,000 / 34,301,000=9.055$

$\mathrm{Y}$ us/Y can $=14.256\left(10^{\wedge} 12\right) / 1.33\left(10^{\wedge} 12\right)=10.718$

Output per worker=Pat us/Pat can $\times \mathrm{L}$ us L can $=1.1836$

Per capita Income for Canada and the US in 2009:

$\$ 63,900 \times \mathrm{E} \times$ change rate $\$ 1.0 \mathrm{CAN} / \$ 1.23277 \mathrm{US}=\$ 51,951$

$\$ 51951($ after ta $\times) / \$ 49,777=1.0436$ or $4.36 \%$

Proportion of workforce participation:
Canada

$(18368700+8 \%$ unemployed $) / 34301,000=57.8 \%$

US:

1,545,000,000 (incl unemployed)/310, 622,000 $=50.70 \%$

Therefore $(57.8 \%-50.70 \%) / 50.7 \%=14 \%$

From above:

$1836 \%-14 \%=4.36 \%$

so, $1.0436 /(18.36-14 \%)=1.00$

Therefore, Canadians earn the same as their US counterparts. If we look at the Environmental perspective, if the price of $\mathrm{M}$, materials increase (scarce natural resources), then either the Y Productive output must increase, the Pat Patents must increase or the L Labour must decrease (unemployment increase) or decrease the number of workers i.e., the population Either this means that we get smarter with better patents, have a lower standard of living, or endure higher unemployment or have less population. If we ask the question, why is Saint John so run down, the answer is that the citizens are poor. Why are they poor? Because their parents were poor. Why were their parents poor? Because they had no jobs: Why did they have no jobs? Because companies were moving out instead in to the City. Why were the companies moving out? Because there were not enough dollar circulating to reach critical mass. Government and Corporate Executives decided against Saint John in favor of Toronto or Halifax or even Moncton [1,2].

Saint john has no future unless immigrants decide to move here despite the poor economy. A city can't grow beyond its hinterland. Saint John has the same regional area as Toronto, but doesn't have the hinterland. A region is supposed to be $2.5 \%$ of the hinterland. Saint john has no hinterland for a modern first world economy. If Canada had economic rights that Pierre Elliott Trudeau wrote about in his Charter of Human Rights, the system would collapse, due to inefficient allocation of resources. The poor would not have the foresight to manage money in an efficient way. The inefficiency would cause the economy to collapse as did Marxism in the U.S.S.R. in about 80 years' time. "The poor you will have with you always."

\section{Conclusion}

So, we see that mathematics from Physics can and should be used to be applied to Economic problems. The mathematics is well understood and thus sheds light on these sorts of problems such as population density and optimum taxation.

\section{References}

1. Cusack P, Saint J (2010) How Politics Killed a Boom Town. New Brunswick.

2. Cusack P (2010) Engineered Solutions to Economic Problems. LULU, New Brunswick. 